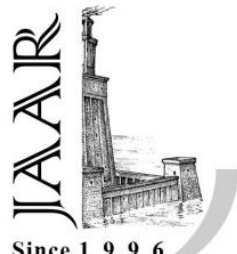

\title{
Contribution of Nano-Silica in Affecting Some of the Physico-Chemical Properties of Cultivated Soil with the Common Bean (Phaseolus vulgaris)
}

Since 1996

Abdullah Hassan Al-Saeedi

Department of Environmental and Natural Resources, College of Agricultural and Food Sciences, King Faisal University, P. O. Box 420, Al-Hassa 31982, Saudi Arabia aalsaeedi@kfu.edu.sa

$$
\text { DOI: } 10.21608 / \text { jalexu.2020.189536 }
$$

Article Information

Received:October $25^{\text {th }} 2020$

Revised:October $27^{\text {th }} 2020$

Accepted:December10 $0^{\text {th }}$ 2020

Published:August11 ${ }^{\text {st } 2021}$
ABSTRACT:Nano-silica can be used as a soil amendment to improve the physicochemical properties and crop productivity. Five rates of Nano-silica

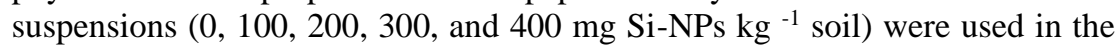
current experiment to investigate the effects of Nano-silica on some chemical and physical properties added to sandy loam soil before bean plant cultivation during the 2018-2019 season. This experiment used a random complete design with three replicates. According to the findings, nano-silica rates have a substantial impact on the percentage of clay particles, cation exchange capacity (CEC), sodium adsorption rate (SAR), porosity, saturation percentage, specific surface area (SSA), total $\mathrm{N}$, and $\mathrm{Si}^{+4}$. With increasing nano-silica rates salinity (EC), $\mathrm{Ca}^{++}$, and $\mathrm{Mg}^{++}$decreased due to the additional uptake by plant, the bean crop yield increased with the increase of nano-silica (Si-NPs) treatments up to $200 \mathrm{mg} . \mathrm{kg}^{-1}$ and reduced with increasing (Si-NPs) at $400 \mathrm{mg} \cdot \mathrm{kg}^{-1}$.

KEYWORDS: Nanosilica, CEC, pH, Bean (Phaseolus vulgaris), Porosity, Crop Yield, Specific Surface Area, SAR.

INTRODUCTION Silicon ( $\mathrm{Si}$ ) is the second most abundant element in the earth's crust. Although all plants contain silicon $(\mathrm{Si})$ in their tissues, the concentration among plant species ranges from 0.1 to $10 \%$ on a dry weight basis (Epstein, 2009). Silicon exists primarily in the form of mineral silicates, alumino-silicates, and silicon dioxide $\left(\mathrm{SiO}_{2}\right)$, however, most of these forms are unattainable to the plants. As the only molecular species that can cross the root plasma membrane at physiological $\mathrm{pH}$, and plants can absorb silicon only in the form of mono silicic acid $\left(\mathrm{H}_{4} \mathrm{SiO}_{4}\right)$, which naturally exists in the soil (Raven, 2001). However, the concentration depends on soil texture, properties, $\mathrm{pH}$, organic matter, minerals present (Tubaña \& Heckman, 2015), and soil moisture conditions (Ma \& Takahashi, 2002; Takahashi, 1974). Many research studies have demonstrated that the positive contribution of silicon on the physical, biochemical and molecular alteration in plants alleviates plant tolerance to abiotic stress (drought, salinity, and heavy metals, et al.) and biotic stress (bacteria, fungi, viruses, insects, and herbivores) (Al-Huqail et al., 2019; A. Alsaeedi et al., 2017, 2018, 2019; Etesami \& Jeong, 2018; Javaid et al., 2019; Manivannan et al., 2016; Mathur \& Roy, 2020; Romero, 2011; Ullah et al., 2016).

Mesoporous silica nanoparticles (Si-NPs) have fascinated researchers over the last decade due to their unique and multifaced physiochemical properties (Jeelani et al., 2020). Silica nanoparticle (Si-NPs) is non-toxic for the plant, is small in size at between $10-100 \mathrm{~nm}$, has a highly specific surface area reach $350 \mathrm{~m}^{2} \cdot \mathrm{g}^{-1}$, and has great absorption capacity by the plant cells (Asgari et al., 2018; Jeelani et al., 2020; Rastogi et al., 2019). Rastogi et al. (2019) and Mathur \& Roy, (2020) reviewed the benefits and the impactions of using silica nanoparticles (Si-NPs) on plant and agricultural productivity. Other studies showed a positive impact of using silica nanoparticles ( $\mathrm{Si}$ NPs) during the different plant growth (A. Alsaeedi et al., 2017, 2018, 2019; Karunakaran et al., 2013; Mathur \& Roy, 2020; Rastogi et al., 2019; Suriyaprabha et al., 2012; Yuvakkumar et al., 2011). It is known that the synthetic silica nanoparticles (Si-NPs) have the same quality and functionality as a source for the beneficial element Si similar to natural silica, but with a non-toxic effect (Asgari et al., 2018; Karunakaran et al., 2013; Nazaralian et al., 2017; Schaller et al., 2019).

As silicic acid or nanoparticles, silicon improves the nutrient availability in soil and the uptake capacity by plants. The positive correlation between phosphorus (P) availability and mobilization in soil with silicon content was demonstrated by (Neu et al., 2017; Schaller et al., 2019; Schaller, Frei, et al., 2020). Silicon improved nutrient uptake by plants, i.e., nitrogen and phosphorus (Neu et al., 2017; Seyfferth \& Fendorf, 2012; Subramanian \& Gopalswamy, Journal Article (C) 2021 by (JAAR) is licensed under CC BY-NC 4.0 CC) 
1991), potassium (Pati et al., 2016; Singh et al., 2005), iron (Mali \& Aery, 2009), and macro and micronutrients as cited by (Adams et al., 2020; A. Alsaeedi et al., 2019). Also, soil water storage capacity was significantly improved with the application of silica nanoparticles (Schaller, Cramer, et al., 2020; Schaller, Frei, et al., 2020).

Sandy soil characterized with scantly physicochemical properties made it improper for efficient agricultural production as it resulted in low water retention and high infiltration rates, poor structural development, neglected organic matter, clay content, and easily lost nutrients via leaching (El-Saied et al., 2016; Hartmann \& Lesturgez, 1995).

The common bean (Phaseolus vulgaris) is considered the most important cultivated legume in the world. Its cultivation is of vital importance along with maize. These two food items constitute the diet of a large part of the world population, providing the largest part of the protein (ArenasRomero et al., 2013).

This work investigates the effect of applying silica nanoparticles (Si-NPs) to the plant, through the soil, on some physical and chemical properties of root zone soil.

\section{MATERIAL AND METHODS}

\subsection{Greenhouse experiment:}

A greenhouse experiment was carried out at the Agricultural and Veterinary Training Research Station at King Faisal University in Al-Hassa, Saudi Arabia, in 2016-2017. The soil at the experimental site was sandy (sand $99.48 \%$, silt $0.25 \%$, and clay $0.27 \%$ ), having a $\mathrm{pH}(7.5)$, salinity (832 ppm), and OM $(<0.05 \%)$. Random complete design with three replicates was conducted in a greenhouse. Five treatments of synthesized hydrophilic silica nanoparticles (SiNPs) (Aerosil 300 produced by Evonik Industries, Germany) were applied Si-NPs at rates 0, 100, 200, 300, $400 \mathrm{mg} \cdot \mathrm{kg}^{-1}$ to the soil before the transplanting of the common bean plant. Fertilizers (NPK) were supplied equally for all treatments according to the local program. The distance between rows was $75 \mathrm{~cm}$ and between two plants in the same row was $50 \mathrm{~cm}$ each.

\subsection{Soil preparation and analysis}

The soil samples were collected from the surface at a depth of 0-50 cm after harvesting. The soil was air-dried and sieved using a square hole sieve of 2 $\mathrm{mm}$ mesh to remove stones and other residual materials. Soil salinity, $\mathrm{pH}$, cation exchange capacity (CEC), Sodium absorption rate (SAR), total nitrogen $\left(\mathrm{N}^{-3}\right)$, Calcium $\left(\mathrm{Ca}^{++}\right)$, Magnesium $\left(\mathrm{Mg}^{++}\right)$, Sodium $\left(\mathrm{Na}^{+}\right)$, silicon $\left(\mathrm{Si}^{+4}\right)$, and saturation percentage $(\%)$ were measured according to (Frantz et al., 2008; Sparks et al., 2020). Soil particle analysis (clay), Specific surface area (SSA), and porosity were quantified (Klute, 1986).

\subsection{Statistical analysis}

All data were analyzed statistically by the XLSTAT software package. Experiments were set up in a completely randomized design with three replicates for each treatment. When a significant difference was observed between treatments, multiple comparisons were made by Fisher's test. Significant differences were accepted at the $p$ level $\leq 0.05$.

\section{RESULTS AND DISCUSSIONS \\ 3.1 Physical properties \\ 3.1.1 Clay percentage}

Analysis of variance showed a significant increase in the percentage of clay among the four treatments compared to the zero Si-NPs treatment (control), as shown in Table 1 and Fig. (1). The result was highly expected due to the nanosize of the added silica. Nanoparticles, including clay and Si-NPs, increased tenfold at Si-NPs400 more than the control. Analysis of variance resulted in a highly positive significant relationship between the treatment and clay percentage $p<0.0001$ and high correlation $(\mathrm{R}=0.98)$. The increase in nanomaterial in sandy soil environments adds a colloidal effect which can enhance the soil hydraulics and chemical properties (Goldberg et al., 2011). As reported by Kim et al. (2014), nanosilica showed a highly negative zeta potential charge in the $\mathrm{pH}$ ranging from 3-13. Through water absorption, Si-NPs is turned into a viscous gel behaving like a clay colloid and consequently increases the bonding and connections between particles (Changizi \& Haddad, 2016).

\subsubsection{Porosity}

High correlations were found between Si-NPs treatments and porosity ( $\mathrm{R}=0.96)$ Figure (1B). Also, $p=0.00013$ (Table 1) indicated that the pore volume increased in the soil as we add Si-NPs. Nanoparticles accumulated in the large pores of sandy soil to create a new microporosity inside the macropores. However, that reflected positively on the overall porosity. This finding results are in agreement with the other research studies (Bayat et al., 2019; Ben-Moshe et al., 2013; Zhang, 2007).

\subsubsection{Saturation}

The saturation percentage increased by $36 \%$ from the control (Si-PNs0) to the fifth treatment ( $\mathrm{Si}$ NPs400). The highly significant value of $p<0.0001$ and correlation coefficient $(\mathrm{R}=0.99)$ (Table 1 and Fig. 1C) indicated the direct and high effect of nano-silica on the hydraulic properties of soil. This increase was due to the increase in microporosity percentages, and the increase of negative charges contributed from nano-silica particles. Many researchers similarly presented these results who reported an increase in saturation in different soil 
types (Bayat et al., 2019; Pérez-Hernández et al., 2020; Ren \& Hu, 2014; Schaller, Cramer, et al., 2020).

\subsubsection{Specific surface area (SSA)}

Although a small quantity of Si-NPs was added to the soil, the effect was tremendously large, as shown in Figure (1D) and Table (1). The increases in SSA reached $80 \%$ (about $141 \mathrm{~m}^{2} \mathrm{~g}^{-1}$ ) compared to the control with $\mathrm{Si}-\mathrm{NPs} 400$. Table (1) shows a highly significant $p<0.0001$, and the correlation coefficient $(\mathrm{R})$ was equal to 0.98 . SSA is the most effective property in the soil at Si-NPs treatment, leading to many Physico-chemical properties changes (Ghormade et al., 2011; Pérez-Hernández et al., 2020). Bayat et al. (2019) stated the positive effects of different nanomaterials on soil surface area using magnesium oxide $\mathrm{MgO}$.

\subsection{Chemical Properties}

\subsubsection{Salinity (EC)}

Soil soluble salts depicted in Table (1) and Figure (1G) show a high negative correlation $(\mathrm{R}=-0.99)$ and a significant effect of $\mathrm{Si}-\mathrm{NPs}$ treatment $p<0.0001$, salts concentration in soil reduced as $\mathrm{Si}-$ NPs treatment increased. That could be due to the low level of cations and anions in the soil, as discussed later in this paper.

\subsubsection{Cation exchangeable capacity (CEC)}

As the value of CEC is always positively related to the specific surface area of the soil, the increase of the CEC value in this experiment was highly anticipated with the addition of nano-silica. SiNPs400 increased the CEC up to $20 \%$ versus the control $(\mathrm{Si}-\mathrm{NPs}=0)$. The analysis of the variance Table (1) showed highly significant effects from Si-NPs treatments $p, 0.0001$. Correlation, Figure (1E), is also highly significant $(\mathrm{R}=0.99)$. Also, there is a positive high significant correlation between CEC and SSA and high correlation $(\mathrm{R}=0.97)$ Figure $(1 \mathrm{~F})$. The result of this paper agrees with results from other researchers who examined the effects of nanomaterials (El-Saied et al., 2016; Fitriatin et al., 2018; Rihayat et al., 2018).

\section{$3.2 .2 \mathrm{pH}$}

Soil $\mathrm{pH}$ did not show a significant relationship with soil $\mathrm{Si}^{+4}$ content $(\mathrm{R}=0.05)$ Figure $(1 \mathrm{H})$, although analysis of variance for Si-NPs treatments showed a slightly significant $p=0.009$ with a correlation coefficient $(\mathrm{R}=0.89)$ Table (1). Si-NPs200 and Si-NPs300 had the highest $\mathrm{pH}$ with values of 7.35 and 7.30, respectively Figure $(1 \mathrm{H})$. Si-NPs has a low $\mathrm{pH}$ ranging between 3.7-4.5. The slight increase in $\mathrm{pH}$ value in Si-NPs200 and SiNPs 300 could be a result of the increase in nutrient solubility in the soil such as $\mathrm{Na}^{+}$and decrease of some due to the excellent growth and crop yields such as $\mathrm{Ca}^{++}$and $\mathrm{K}^{+}$content (Al-Busaidi \& Cookson, 2003; Kool et al., 2011).

3.2.3 Calcium and Magnesium soil content $\left(\mathrm{Ca}^{++}, \mathrm{Mg}^{++}\right)$
The results shown in Table (1) demonstrated the highly significant effect of Si-NPs addition with calcium $p<0.0001$ Figure (1A) and less significance with magnesium $p=0.001$. Calcium content decreased in the soil as $\mathrm{Si}$ content increased Figure (1A). In this study, $\mathrm{Ca}^{++}$and $\mathrm{Mg}^{++}$content in the soil decreased as $\mathrm{Si}^{+4}$ content increased with negative correlation (-0.99) and (0.95), respectively Figures (2B\&D). The explanation for this could be due firstly to $\mathrm{Si}$ increasing the solubility and mobility of nutrients in the soil, making it readily available to plant (Aqaei et al., 2020), and secondly to the improvement in the plant growth and metabolism process which maximized nutrient uptake by the root, in particular, $\mathrm{Ca}^{++}$and $\mathrm{Mg}^{++}$(Ditta \& Arshad, 2016; Mathur \& Roy, 2020).

\subsubsection{Sodium $\left(\mathrm{Na}^{+}\right)$}

Data analysis of the effect of Si-NPs on the level of sodium in the soil did not show any significant difference between all treatments except Si-NPs400, which is $14 \%$ higher than others Table (1) and Figures (2E\&F). It is well documented that silicon reduces the plant's sodium uptake (Ahmad et al., 1992; A. H. Alsaeedi et al., 2017; Yeo et al., 1999). Figure (2F) shows no significant relationship between silicon content in the soil and sodium content with a poor correlation coefficient. The accumulated sodium in the soil due to root absorption selectivity under silicon treatment could be affected by the irrigation water, which leaches sodium and weakens bonds outside the root zone (Matthew \& Akinyele, 2014). That could explain the nonsignificant effect of Si-NPs treatments 0-300 on sodium content in the soil.

\subsubsection{Sodium Adsorption Ratio (SAR)}

The high value of unutilized or excluded sodium in the soil due to the silicon's positive effect on the root absorption mechanism was reflected in SAR values (Table 1 and Fig. 2G). For this reason, SiNPs400 recorded the highest SAR with $20 \%$ average increases compared with other treatments. Si-NPs400 showed a highly significant effect $p<0.0001$ with all other treatments. SAR demonstrates the same behaviour as sodium in this study.

\subsubsection{Nitrogen $(\mathbf{N})$}

Analysis of the variance showed the highly significant effect of Si-NPs treatments on nitrogen levels in the soil $p<0.0001$ as shown in Table (1). The relation between nitrogen and silicon content in soil showed a high correlation $(\mathrm{R}=0.99)$ as depicted in Figures (3A\&B). SiNPs400 reported the highest value of nitrogen $0.028 \%$ with an increase of $16 \%$, Si-NPs300 also reported a significant difference compared to zero Si-NPs with a value of $0.027 \%$. Si-NPs200 and 100 as well showed a significant increase in nitrogen content of 0.026 and 0.025 , respectively. The enhancement of nitrogen content in the soil 
was referred to as the positive effect of silicon on the microorganisms in the soil, which improved the organic content in the soil (Bocharnikova \& Matichenkov, 2010; Xu et al., 2020) and to the positive effect of silicon in reducing the nitrogen leaching from soil (Bocharnikova \& Matichenkov, 2010; Matichenkov et al., 2020; Matichenkov \& Bocharnikova, 2001).

\subsubsection{Silicon $\left(\mathbf{S i}^{+4}\right)$}

As expected, the value of soil silica was increased significantly as Si-NPs treatment increased with $p<0.0001$ Table (1). Figure (3D) shows that Si-NPs400 recorded the highest silicon content, $190.74 \mathrm{mg} \mathrm{kg}^{-1}$, then Si-NPs300, 200, and 100 with a value of $139.81,95.83$, and $61.11 \mathrm{mg}$ $\mathrm{kg}^{-1}$, respectively. Many researchers report similar results for directly increasing soil content from silicon linearly with the added amount or dosage (Ma \& Takahashi, 2002; Matichenkov et al., 2020; $\mathrm{Xu}$ et al., 2020).

\subsection{Yield}

The analysis of variance showed a significant effect of Si-NPs applications in improving the final yield of common bean (as bean) $\mathrm{p}<0.0001$, as indicated in Table (1). Si-NPs300 demonstrated the maximum yield of $63.27 \mathrm{~g} \mathrm{plant}^{-1}, \mathrm{Si}-\mathrm{NPs} 400$, 200,100, and 0 showed 59.30, 58.27, 57.26, and 55.57 respectively Figure (3E). Si-NPs400 showed a reduction of $7.2 \%$, Si-NPs200 reduction was equal to $8.8 \%$, Si-NPs100 also showed a reduction of $10.4 \%$. Finally, Si-NPs0 showed a reduction in yield reached $13 \%$. These results, supported by many references and research studies, prove silicon's positive effect in increasing the yield and physiological operation during plant life ( Alsaeedi et al., 2017, 2019; Etesami \& Jeong, 2018; Javaid et al., 2019).

\section{CONCLUSION}

It can be inferred that adding nano-silica to soil increased of the clay soil content, and consequently, the saturation percentage, specific surface area (SSA), cation exchange capacity (CEC), porosity, and sodium adsorption ratio (SAR). At the Si-NPs200 rate, the improvement of these properties enhanced the total nitrogen $(\mathrm{N})$ in the soil and accordingly increased the yield of the common bean. The use of nano-silica particles in soil reduced the average of salinity, soluble $\mathrm{Ca}^{2+}$, and $\mathrm{Mg}^{2+}$. 
Table 1: Mean of a square of clay, porosity, saturation, SSA, salinity (EC), pH, cation exchange capacity (CEC), soluble $\mathrm{Ca}^{2+}, \mathrm{Mg}^{2+}$ and $\mathrm{Na}^{+}$, $\mathrm{Sodium}$ adsorption ratio (SAR), available nitrogen $(\mathrm{N})$, soluble silicon $\left(\mathrm{Si}^{+4}\right)$ in the soil after pean harvesting of pean and the yield under the effect of different rates of $\mathrm{Nano}$-silica amendment.

\begin{tabular}{|c|c|c|c|c|c|c|c|c|c|c|c|c|c|c|c|}
\hline \multirow{2}{*}{$\begin{array}{l}\text { Source of } \\
\text { variation }\end{array}$} & \multirow{2}{*}{$\begin{array}{l}\text { Degree } \\
\quad \text { of } \\
\text { Freedom }\end{array}$} & \multicolumn{14}{|c|}{ Mean Squares } \\
\hline & & Clay & Porosity & Saturation & SSA & $\begin{array}{c}\text { Salinity } \\
\text { (EC) }\end{array}$ & CEC & pH & $\mathbf{C a}^{2+}$ & $\mathbf{M g}^{2+}$ & $\mathbf{N a}^{+}$ & SAR & $\mathbf{N}$ & $\mathrm{Si}^{+4}$ & Yield \\
\hline & & $(\%)$ & $\left(\mathrm{cm}^{3} \mathrm{~cm}^{-3}\right)$ & $\left(\mathrm{g} \mathrm{g}^{-1}\right)$ & $\left(\mathrm{m}^{2} \mathrm{~g}^{-1}\right)$ & (ppm) & $\left(\mathrm{cmolc} \mathrm{kg}^{-1}\right)$ & & $\left(\right.$ meq L L $\left.^{-1}\right)$ & 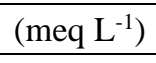 & $\left(\right.$ meq L L $\left.^{-1}\right)$ & & $(\%)$ & $\left(\mathrm{mg} \mathrm{kg}^{-1}\right)$ & $\left(\mathrm{g}_{\text {plant }}{ }^{-1}\right)$ \\
\hline Replications & 2 & $1.63 \mathrm{E}-06$ & 0.000086 & 7.27E-06 & 228.54 & 2072.63 & 0.0095 & 0.0008 & 0.0005 & 0.0029 & 0.0024 & 0.0029 & 6.66E-08 & 99.666 & 1.5650 \\
\hline $\begin{array}{l}\text { Si-NPs } \\
\text { Treatment }\end{array}$ & 4 & 0.00032 & 0.0035 & 0.00195 & 6827.47 & 1022792.22 & 0.5822 & 0.0129 & 0.1533 & 0.0336 & 0.0655 & 0.1704 & 7.56E-06 & 13089.95 & 76.4056 \\
\hline Error & 8 & $4.28 \mathrm{E}-06$ & 0.000142 & 2.93E-06 & 112.35 & 7689.194 & 0.0045 & 0.0018 & 0.0003 & 0.0022 & 0.0074 & 0.0053 & 6.66E-08 & 35.3692 & 0.3900 \\
\hline $\mathbf{R}$ (regression) & & 0.98 & 0.96 & 0.99 & 0.98 & 0.99 & 0.99 & 0.89 & 0.99 & 0.94 & 0.95 & 0.95 & 0.99 & 0.99 & 0.98 \\
\hline$P>\mathbf{F}$ & & $<0.0001$ & 0.00013 & $<0.0001$ & $<0.0001$ & $<0.0001$ & $<0.0001$ & 0.0090 & $<0.0001$ & 0.001 & 0.005 & $<0.0001$ & $<0.0001$ & $<0.0001$ & $<0.0001$ \\
\hline Significant & & $* * * *$ & $* * *$ & $* * * *$ & $* * * *$ & $* * * *$ & $* * * *$ & $* *$ & $* * * *$ & $* * *$ & $* *$ & $* * * *$ & $* * * *$ & $* * * *$ & $* * * *$ \\
\hline LSD @ 0.05 & & 0.003 & 0.022 & 0.003 & 19.96 & 165.103 & 0.127 & 0.080 & 0.036 & 0.088 & 0.162 & 0.138 & $4.86 \mathrm{E}-04$ & 11.197 & 1.176 \\
\hline
\end{tabular}



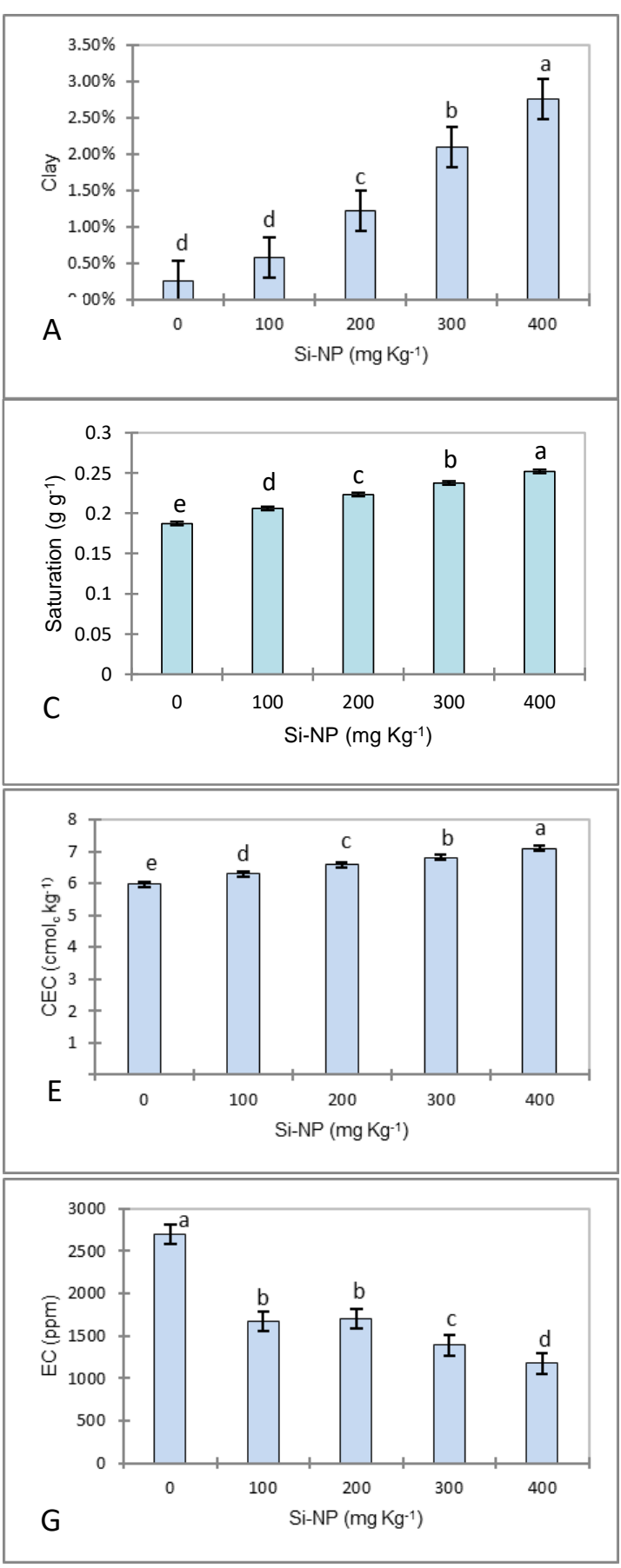
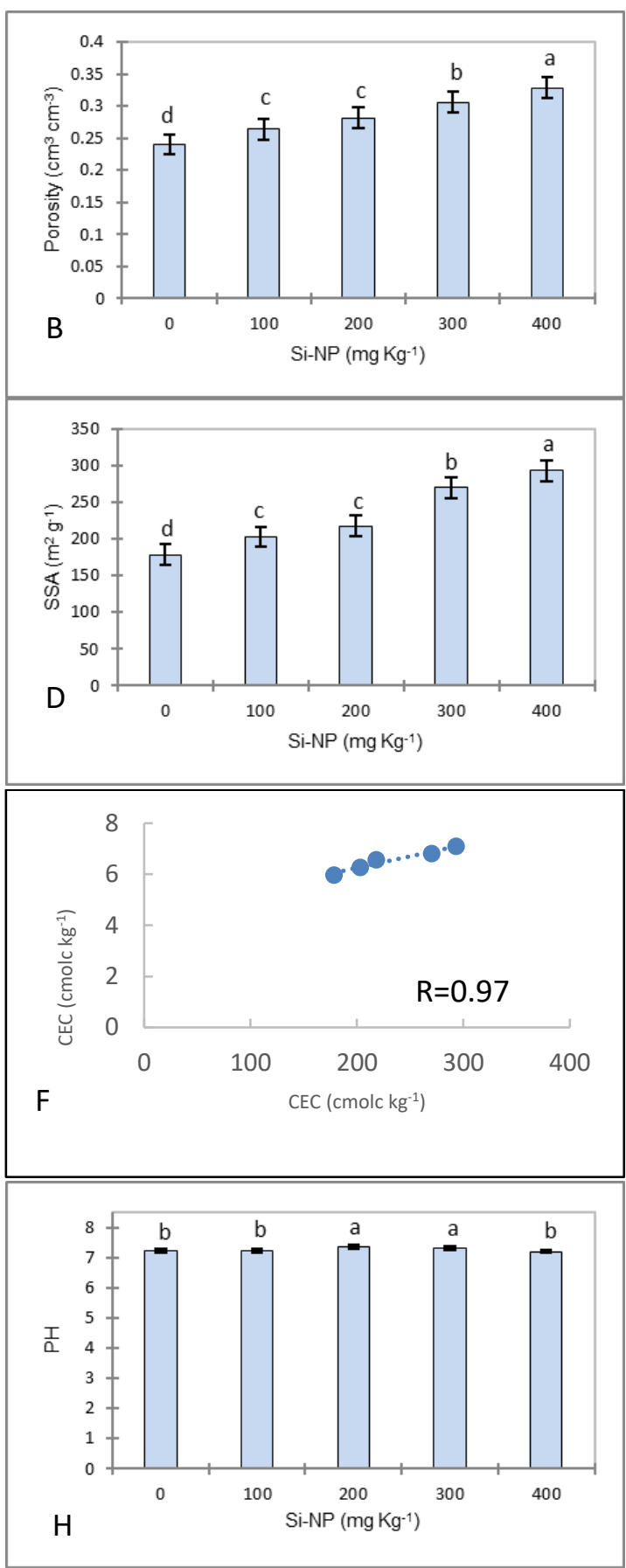

Fig. 1: The change in clay\% (A), porosity $\mathrm{cm}^{3} \mathrm{~cm}^{-3}(\mathrm{~B})$, saturation $\mathrm{cm}^{3} \mathrm{~cm}^{-3}(\mathrm{C})$, specific surface area SSA $\mathrm{m}^{2} \mathrm{~g}^{-}$ ${ }^{1}(\mathrm{D})$, cation exchangeable capacity CEC (E), salinity EC ppm $(\mathrm{G})$ and $\mathrm{pH}(\mathrm{H})$ under the effect of Si.NPs treatments, and correlations coefficient between CEC and specific surface area SSA (F). 
(JAAR) Volume: 25 (4)

A
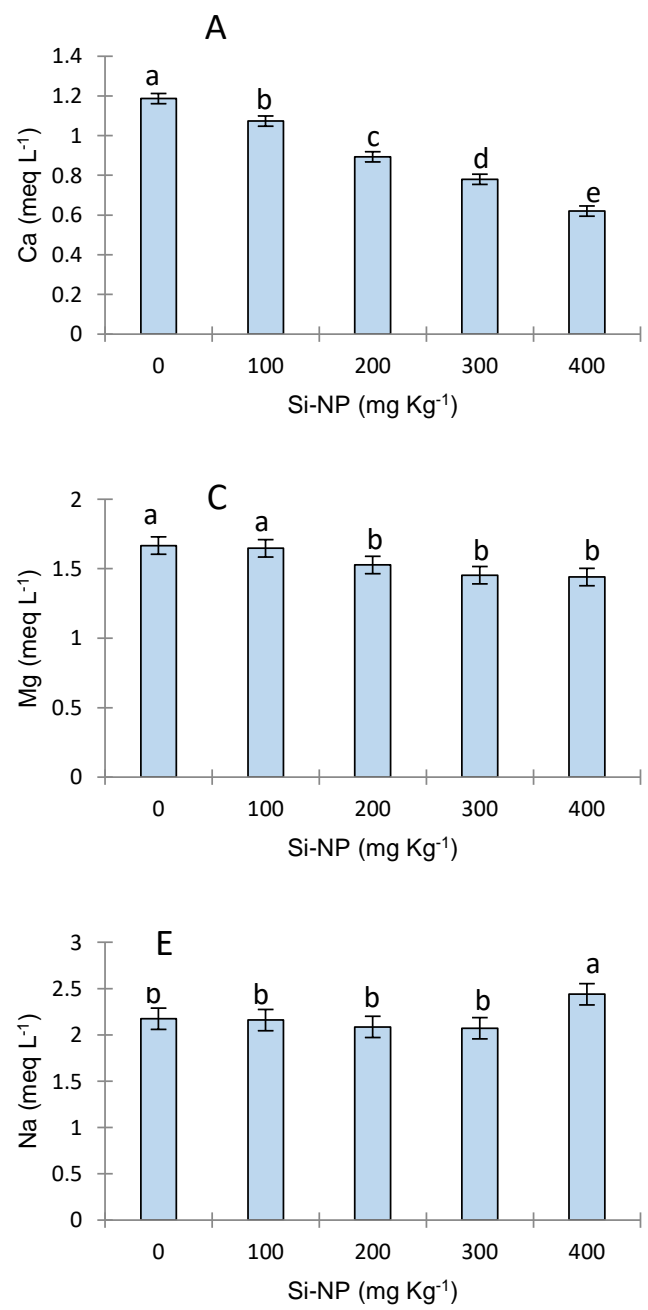

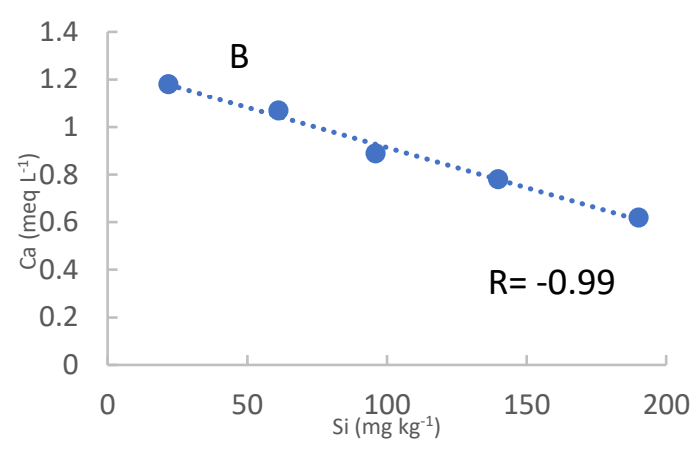

$\mathrm{D}$
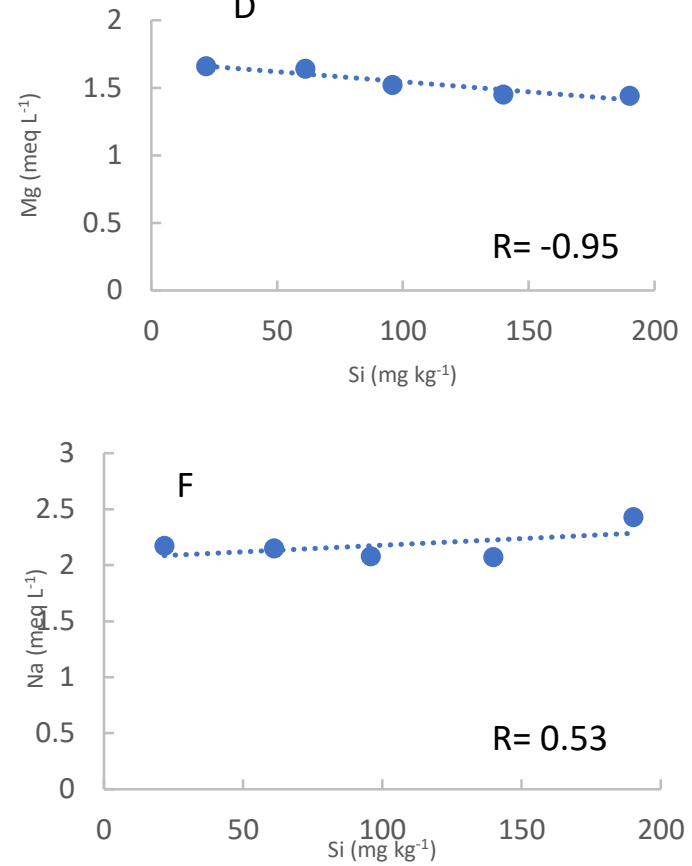

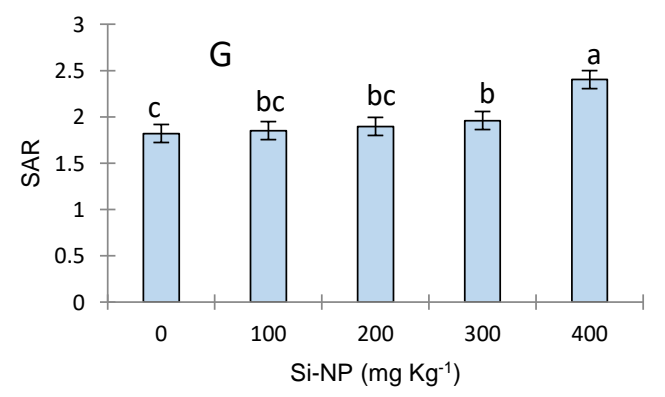

Fig. 2: The change in soluble of Ca meq L-1(A) Mg meq L-1 (C) Na meq L-1 (E) and SAR (G) with $\mathrm{Si}$-NPs treatments. While B, D, and F Figures show the correlation coefficient between $\mathrm{Ca}, \mathrm{Mg}$, and $\mathrm{Na}$ with valuable $\mathrm{Si}$ in soil, respectively meq L-1 under the effects of Nano-silica application rates.
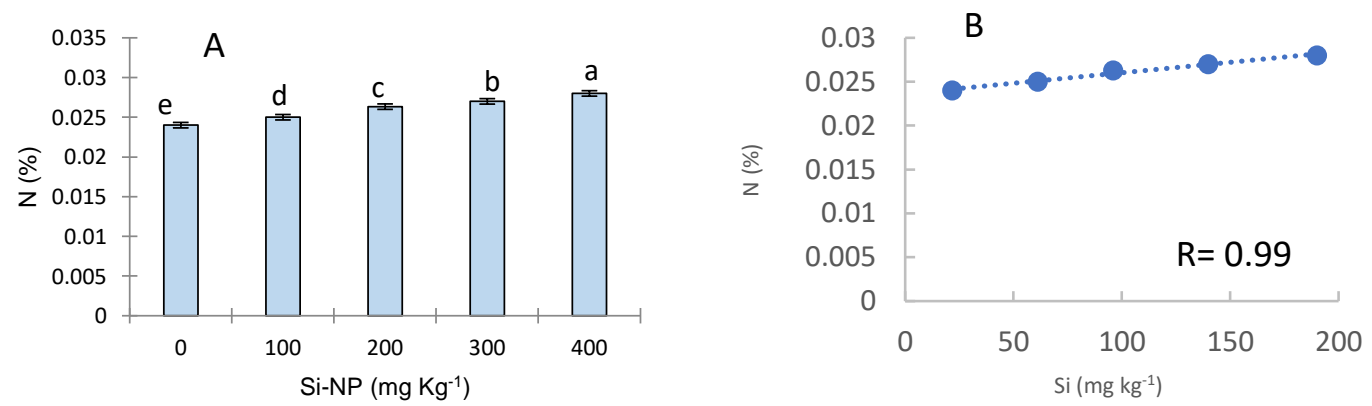

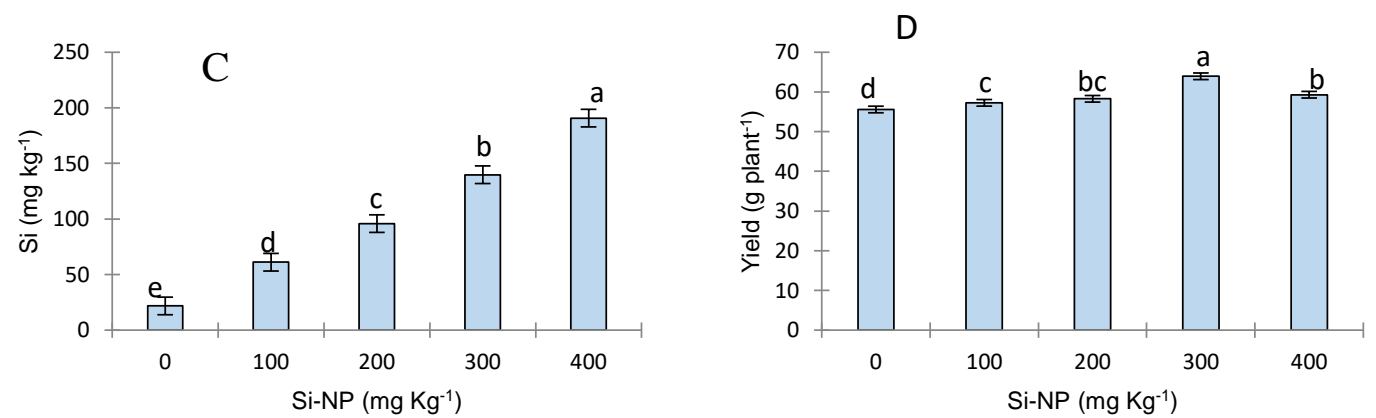

Fig. 3. The effect of Nano-silica application rates to the soil on total N\% (A), soluble $\mathrm{Si} \mathrm{mg} \mathrm{kg}^{-1}$ (C), and the yield of bean crop g plant ${ }^{-1}(\mathrm{D})$, while the figure $\mathrm{B}$ indicates to the correlation coefficient between total $\mathrm{N} \%$ and available Si $\mathrm{mg} \mathrm{kg}^{-1}$.

\section{REFRENCES}

Adams, C. B., Erickson, J. E., \& Bunderson, L. (2020). A mesoporous silica nanoparticle technology applied in dilute nutrient solution accelerated establishment of zoysiagrass. Agrosystems, Geosciences \& Environment, 3(1), $1-9$. https://doi.org/10.1002/agg2.20006

Ahmad, R., Zaheer, S. H., \& Ismail, S. (1992). Role of silicon in salt tolerance of wheat (Triticum aestivum L.). Plant Science, 85(1), 43-50. https://doi.org/10.1016/01689452(92)90092-Z

Al-Busaidi, A., \& Cookson, P. (2003). Salinity $\mathrm{pH}$ Relationships in Calcareous Soils of Oman. Journal for Scientific Research. Agricultural and Marine Sciences, 8(1), 4146.

Al-Huqail, A. A., Alqarawi, A. A., Hashem, A., Ahmad Malik, J., \& Abd_Allah, E. F. (2019). Silicon supplementation modulates antioxidant system and osmolyte accumulation to balance salt stress in Acacia gerrardii Benth. Saudi Journal of Biological Sciences, 26(7), 1856-1864. https://doi.org/10.1016/j.sjbs.2017.11.049

Alsaeedi, A., El-Ramady, H., Alshaal, T., \& Almohsen, M. (2017). Enhancing seed germination and seedlings development of common bean (Phaseolus vulgaris) by $\mathrm{SiO} 2$ nanoparticles. Egyptian Journal of Soil Science, 57(4), 407-415. https://doi.org/10.21608/ejss.2017.891.1098

Alsaeedi, A., El-Ramady, H., Alshaal, T., ElGarawani, M., Elhawat, N., \& Al-Otaibi, A. (2018). Exogenous nanosilica improves germination and growth of cucumber by maintaining $\mathrm{K}+/ \mathrm{Na}+$ ratio under elevated $\mathrm{Na}+$ stress. Plant Physiology and Biochemistry, 125(April 2018), 164-171. https://doi.org/10.1016/j.plaphy.2018.02.00 6

Alsaeedi, A., El-Ramady, H., Alshaal, T., ElGarawany, M., Elhawat, N., \& Al-Otaibi,
A. (2019). Silica nanoparticles boost growth and productivity of cucumber under water deficit and salinity stresses by balancing nutrients uptake. Plant Physiology and Biochemistry, 139(March), 1-10. https://doi.org/10.1016/j.plaphy.2019.03.00 8

Alsaeedi, A. H., El-Ramady, H., Alshaal, T., ElGarawani, M., Elhawat, N., \& Almohsen, M. (2017). Engineered silica nanoparticles alleviate the detrimental effects of $\mathrm{Na}+$ stress on germination and growth of common bean (Phaseolus vulgaris). Environmental Science and Pollution Research, 24(27), 21917-21928. https://doi.org/10.1007/s11356-017-9847-y

Aqaei, P., Weisany, W., Diyanat, M., Razmi, J., \& Struik, P. C. (2020). Response of maize ( Zea mays L.) to potassium nano-silica application under drought stress. Journal of Plant Nutrition, 43(9), 1205-1216. https://doi.org/10.1080/01904167.2020.172 7508

Arenas-Romero, O., Huato-Damián, M. A., Tapia-Rivera, J. A., Simón-Báez, A., Lara-Huerta, M., \& Huerta-Cabrera, E. (2013). The Nutritional value of Beans ( Phaseolus vulgaris $L$.) and its importance for Feeding of Rural communities in PueblaMexico. Journal of Biological Sciences, 2(8), 59-65.

Asgari, F., Majd, A., Jonoubi, P., \& Najafi, F. (2018). Effects of silicon nanoparticles on molecular, chemical, structural and ultrastructural characteristics of oat (Avena sativa L.). Plant Physiology and Biochemistry, 127(March), 152-160. https://doi.org/10.1016/j.plaphy.2018.03.02 1

Bayat, H., Kolahchi, Z., Valaey, S., Rastgou, M., \& Mahdavi, S. (2019). Iron and magnesium nano-oxide effects on some physical and mechanical properties of a loamy Hypocalcic Cambisol. Geoderma, 335, 57- 
68.

https://doi.org/10.1016/j.geoderma.2018.08. 007

Ben-Moshe, T., Frenk, S., Dror, I., Minz, D., \& Berkowitz, B. (2013). Effects of metal oxide nanoparticles on soil properties. Chemosphere, 90(2), 640-646. https://doi.org/10.1016/j.chemosphere.2012. 09.018

Bocharnikova, E. A., \& Matichenkov, V. V. (2010). Theory and practice of silicon fertilizers. Del 6 Al 9 de Octubre de 2010, 5(9), 390. http://orgprints.org/29758/1/actaslleida-vd.pdf\#page $=391$

Changizi, F., \& Haddad, A. (2016). Effect of Nano-SiO2 on the Geotechnical Properties of Cohesive Soil. Geotechnical and Geological Engineering, 34(2), 725-733. https://doi.org/10.1007/s10706-015-9962-9

Ditta, A., \& Arshad, M. (2016). Applications and perspectives of using nanomaterials for sustainable plant nutrition. Nanotechnology Reviews, 5(2), 209-229 https://doi.org/10.1515/ntrev-2015-0060

El-Saied, H., El-Hady, O. A., Basta, A. H., ElDewiny, C. Y., \& Abo-Sedera, S. A. (2016). Bio-chemical properties of sandy calcareous soil treated with rice straw-based hydrogels. Journal of the Saudi Society of Agricultural Sciences, 15(2), 188-194. https://doi.org/10.1016/j.jssas.2014.11.004

Epstein, E. (2009). Silicon: its manifold roles in plants. Annals of Applied Biology, 155(2), 155-160. https://doi.org/10.1111/j.17447348.2009.00343.x

Etesami, H., \& Jeong, B. R. (2018). Silicon (Si): Review and future prospects on the action mechanisms in alleviating biotic and abiotic stresses in plants. Ecotoxicology and Environmental Safety, 147(May 2017), 881896.

https://doi.org/10.1016/j.ecoenv.2017.09.06 3

Fitriatin, B. N., Arifin, M., Devnita, R., Yuniarti, A., Haryanto, R., \& Setiabudi, M. A. (2018). $\mathrm{P}$ retention and cation exchange as affected by nanoparticle of volcanic ash and application of phosphate solubilizing bacteria on Andisol Ciater, West Java, Indonesia. AIP Conference Proceedings, 1927, 030025 . https://doi.org/10.1063/1.5021218

Frantz, J. M., Locke, J. C., Datnoff, L., Omer, M., Widrig, A., Sturtz, D., Horst, L., \& Krause, C. R. (2008). Detection, Distribution, and Quantification of Silicon in Floricultural Crops utilizing Three Distinct Analytical Methods. Communications in Soil Science and Plant Analysis, 39(17-18), 2734-2751. https://doi.org/10.1080/0010362080235891 2

Ghormade, V., Deshpande, M. V., \& Paknikar, K. M. (2011). Perspectives for nanobiotechnology enabled protection and nutrition of plants. Biotechnology Advances, 29(6),

792-803.

https://doi.org/10.1016/j.biotechadv.2011.0 6.007

Goldberg, S., Lebron, I., Seaman, J. C., \& Suarez, D. L. (2011). Soil Colloidal Behavior. In P. M. Huang, Y. Li, \& M. E. Sumner (Eds.), Handbook of Soil Sciences Properties and Processes. Routledge Handbooks Online. https://doi.org/10.1201/b11267-17

Hartmann, C., \& Lesturgez, G. (1995). Physical properties of tropical sandy soils: A large range of behaviours. Group, v, 1-10. http://www.archive.org/details/plantrelation sfi00coul

Javaid, T., Farooq, M. A., Akhtar, J., Saqib, Z. A., \& Anwar-ul-Haq, M. (2019). Silicon nutrition improves growth of salt-stressed wheat by modulating flows and partitioning of $\mathrm{Na}^{+}, \mathrm{Cl}-$ and mineral ions. Plant Physiology and Biochemistry, 141(June), 291-299.

https://doi.org/10.1016/j.plaphy.2019.06.01 0

Jeelani, P. G., Mulay, P., Venkat, R., \& Ramalingam, C. (2020). Multifaceted Application of Silica Nanoparticles. A Review. Silicon, 12(6), 1337-1354. https://doi.org/10.1007/s12633-019-00229y

Karunakaran, G., Suriyaprabha, R., Manivasakan, P., Yuvakkumar, R., Rajendran, V., Prabu, P., \& Kannan, N. (2013). Effect of nanosilica and silicon sources on plant growth promoting rhizobacteria, soil nutrients and maize seed germination. IET Nanobiotechnology, 7(3), 70-77. https://doi.org/10.1049/ietnbt.2012.0048

Kim, K. M., Kim, H. M., Lee, W. J., Lee, C. W., Kim, T. Il, Lee, J. K., Jeong, J., Paek, S. M., \& Oh, J. M. (2014). Surface treatment of silica nanoparticles for stable and chargecontrolled colloidal silica. International Journal of Nanomedicine, 9, 29-40. https://doi.org/10.2147/IJN.S57922

Klute, A. (Ed.). (1986). Methods of Soil Analysis. Soil Science Society of America, American Society of Agronomy. https://doi.org/10.2136/sssabookser5.1.2ed

Kool, P. L., Ortiz, M. D., \& Van Gestel, C. A. M. (2011). Chronic toxicity of $\mathrm{ZnO}$ nanoparticles, non-nano $\mathrm{ZnO}$ and $\mathrm{ZnCl} 2$ to Folsomia candida (Collembola) in relation to 
bioavailability in soil. Environmental Pollution, 159(10), 2713-2719. https://doi.org/10.1016/j.envpol.2011.05.02 1

Ma, J. F., \& Takahashi, E. (2002). Soil, Fertilizer, and Plant Silicon Research in Japan. In Soil, Fertilizer, and Plant Silicon Research in Japan. Elsevier. https://doi.org/10.1016/B978-0-444-511669.X5000-3

Mali, M., \& Aery, N. C. (2009). Effect of Silicon on Growth, Biochemical Constituents, and Mineral Nutrition of Cowpea. Communications in Soil Science and Plant Analysis, 40(7-8), 1041-1052. https://doi.org/10.1080/0010362090275359 0

Manivannan, A., Soundararajan, P., Muneer, S., Ko, C. H., \& Jeong, B. R. (2016). Silicon mitigates salinity stress by regulating the physiology, antioxidant enzyme activities, and protein expression in Capsicum annuum "Bugwang." BioMed Research International, 2016. https://doi.org/10.1155/2016/3076357

Mathur, P., \& Roy, S. (2020). Nanosilica facilitates silica uptake, growth and stress tolerance in plants. Plant Physiology and Biochemistry, 157(May), 114-127. https://doi.org/10.1016/j.plaphy.2020.10.01 1

Matichenkov, V., Bocharnikova, E., \& Campbell, J. (2020). Reduction in nutrient leaching from sandy soils by $\mathrm{Si}$-rich materials: Laboratory, greenhouse and filed studies. Soil and Tillage Research, 196(September 2019), 104450. https://doi.org/10.1016/j.still.2019.104450

Matichenkov, V. V., \& Bocharnikova, E. A. (2001). The relationship between silicon and soil physical and chemical properties V. In Lawrence E. Datnoff, G. H. Snyder, \& G. H. Korndörfer (Eds.), Silicon in Agriculture (pp. 209-219). Elsevier Science B.V. https://doi.org/10.7551/mitpress/12605.003. 0016

Matthew, A., \& Akinyele, A. (2014). Sodium and Calcium Salts Impact on Soil Permeability. Journal of Earth Sciences and ..., 4(3), 3745.

http://www.scienpress.com/Upload/GEO/V ol 4_3_3.pdf

Nazaralian, S., Majd, A., Irian, S., Najafi, F., Ghahremaninejad, F., Landberg, T., \& Greger, M. (2017). Comparison of silicon nanoparticles and silicate treatments in fenugreek. Plant Physiology and Biochemistry, $\quad 115, \quad 25-33$ https://doi.org/10.1016/j.plaphy.2017.03.00 9
Neu, S., Schaller, J., \& Dudel, E. G. (2017). Silicon availability modifies nutrient use efficiency and content, $\mathrm{C}: \mathrm{N}: \mathrm{P}$ stoichiometry, and productivity of winter wheat (Triticum aestivum L.). Scientific Reports, 7. https://doi.org/10.1038/srep40829

Pati, S., Pal, B., Badole, S., Hazra, G. C., \& Mandal, B. (2016). Effect of Silicon Fertilization on Growth, Yield, and Nutrient Uptake of Rice. Communications in Soil Science and Plant Analysis, 47(3), 284-290. https://doi.org/10.1080/00103624.2015.112 2797

Pérez-Hernández, H., Fernández-Luqueño, F., Huerta-Lwanga, E., Mendoza-Vega, J., \& Álvarez-Solís José, D. (2020). Effect of engineered nanoparticles on soil biota: Do they improve the soil quality and crop production or jeopardize them? Land Degradation and Development, 31(16), 2213-2230. https://doi.org/10.1002/ldr.3595

Rastogi, A., Tripathi, D. K., Yadav, S., Chauhan, D. K., Živčák, M., Ghorbanpour, M., El-Sheery, N. I., \& Brestic, M. (2019). Application of silicon nanoparticles in agriculture. 3 Biotech, 9(3), 1-11. https://doi.org/10.1007/s13205-0191626-7

Raven, J. A. (2001). Chapter 3 Silicon transport at the cell and tissue level. In L E Datnoff, G. H. Snyder, \& G. H. Korndörfer (Eds.), Silicon in Agriculture (Vol. 8, pp. 41-55). Elsevier. https://doi.org/https://doi.org/10.1016/S092 8-3420(01)80007-0

Ren, X., \& Hu, K. (2014). Effect of nanosilica on the physical and mechanical properties of silty clay. Nanoscience and Nanotechnology Letters, 6(11), 1010-1013. https://doi.org/10.1166/nnl.2014.1857

Rihayat, T., Salim, S., Arlina, A., Fona, Z., Jalal, R., Alam, P. N., Zaimahwati, Sami, M., Syarif, J., \& Juhan, N. (2018). Determination of CEC value ( Cation Exchange Capacity ) of Bentonites from North Aceh and Bener Meriah, Aceh Province, Indonesia using three methods. IOP Conference Series: Materials Science and Engineering, 334(1), 012054. https://doi.org/10.1088/1757899X/334/1/012054

Romero, A. (2011). Silicon and plant diseases . A review El silicio y las enfermedades de las plantas . Una revisión. 29(3), 473-480.

Schaller, J., Cramer, A., Carminati, A., \& Zarebanadkouki, M. (2020). Biogenic amorphous silica as main driver for plant available water in soils. Scientific Reports, 10(1), 1-7. https://doi.org/10.1038/s41598020-59437-x 
Schaller, J., Faucherre, S., Joss, H., Obst, M., Goeckede, M., Planer-Friedrich, B., Peiffer, S., Gilfedder, B., \& Elberling, B. (2019). Silicon increases the phosphorus availability of Arctic soils. Scientific Reports, 9(1), 1-11. https://doi.org/10.1038/s41598-018-371046

Schaller, J., Frei, S., Rohn, L., \& Gilfedder, B. S. (2020). Amorphous Silica Controls Water Storage Capacity and Phosphorus Mobility in Soils. Frontiers in Environmental Science, 8(July). https://doi.org/10.3389/fenvs.2020.00094

Seyfferth, A. L., \& Fendorf, S. (2012). Silicate Mineral Impacts on the Uptake and Storage of Arsenic and Plant Nutrients in Rice (Oryza sativa L.). Environmental Science \& Technology, 46(24), 13176-13183. https://doi.org/10.1021/es3025337

Singh, A. K., Singh, R., \& Singh, K. (2005). Growth, yield and economics of rice (Oryza sativa) as influenced by level and time of silicon application. Indian Journal of Agronomy, 3, 190-193.

Sparks, D. L., Page, A. L., Helmke, P. A., \& Loeppert, R. H. (Eds.). (2020). Methods of Soil Analysis, Part 3: Chemical Methods. American Sciety of Agronomy Ins.

Subramanian, S., \& Gopalswamy, A. (1991). Effect of moisture, organic matter, phosphate and silicate on availability of silicon and phosphorus in rice soils. J. Indian Soc. Soil Sci., 39(1), 99-103.

Suriyaprabha, R., Karunakaran, G., Yuvakkumar, R., Prabu, P., Rajendran, V., \& Kannan, N. (2012). Growth and physiological responses of maize (Zea mays L.) to porous silica nanoparticles in soil. Journal of Nanoparticle Research, 14(12). https://doi.org/10.1007/S11051-012-1294-6

Takahashi, E. (1974). Effect of Soil Moisture on the Uptake of Silica by Rice Plant Seedlings. Journal of the Science of Soil and Manure, Japan,

45(12). https://doi.org/10.20710/dojo.45.12_591

Tubaña, B. S., \& Heckman, J. R. (2015). Silicon in Soils and Plants. In Silicon and Plant Diseases (pp. 7-51). Springer International Publishing. https://doi.org/10.1007/978-3319-22930-0_2

Ullah, U., Ashraf, M., Shahzad, S. M., Siddiqui, A. R., Piracha, M. A., \& Suleman, M. (2016). Growth behavior of tomato (Solanum lycopersicum L.) under drought stress in the presence of silicon and plant growth promoting rhizobacteria. Soil and Environment, 35(1), 65-75.

Xu, D., Gao, T., Fang, X., Bu, H., Li, Q., Wang, X., \& Zhang, R. (2020). Silicon addition improves plant productivity and soil nutrient availability without changing the grass:legume ratio response to $\mathrm{N}$ fertilization. Scientific Reports, 10(1), 1-9. https://doi.org/10.1038/s41598-020-673337

Yeo, A. R., Flowers, S. A., Rao, G., Welfare, K., Senanayake, N., \& Flowers, T. J. (1999). Silicon reduces sodium uptake in rice (Oryza sativa $L_{\text {.) }}$ in saline conditions and this is accounted for by a reduction in the transpirational bypass flow. Plant, Cell and Environment, 22(5), 559-565. https://doi.org/10.1046/j.13653040.1999.00418.x

Yuvakkumar, R., Elango, V., Rajendran, V., Kannan, N. S., \& Prabu, P. (2011). Influence of nanosilica powder on the growth of maize crop (Zea Mays L.). International Journal of Green Nanotechnology: Biomedicine, 3(3), 180190. https://doi.org/10.1080/19430892.2011.628 581

Zhang, G. (2007). Soil Nanoparticles and their Influence on Engineering Properties of Soils. Advances in Measurement and Modeling of Soil Behavior, 1-13. https://doi.org/10.1061/40917(236)37 


\title{
الملخص العربي \\ مساهمة النانو سيليكا في التأثير على بعض من الخواص الفيزيائية والكيميائية \\ للتربة المزروعة بالفاصوليا (Phaseolus vulgaris)
}

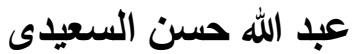 \\ جامعة الملك فيصل ـ كلية العلوم الزر اعية والاغذية ـ قسم البيئة ومصادر طبيعية زر اعية \\ aalsaeedi@kfu.edu.sa
}

في التجربة الحالية تم استخدام خمسة معدلات لمعلقات النانو سيليكا (0 ، 100 ، 200 ، 300 ، 400 ملجم كجم -1 تربة) المضافة إلى التربة الرملية قبل زراعة نبات الفاصوليا في موسم 2018- 2019 لدراسة تأثير النانو سيليكا على بعض من الخواص الكيميائية والفيزيائية. تم استخدام تصميم القطاعات الكاملة بثلاثة مكررات في هذهات

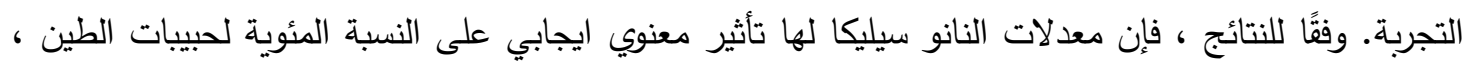

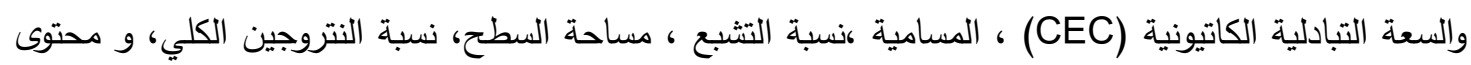
السيليكون في التربة. كما ان المعاملات السابقة لها تأثير سلبي على درجة الملوحة، محتوى الكالسيوم و الماغنسيوم نتيجة زيادة امتصصهما بواسطة النبات. مع زيادة معدلات النانو سيليكا زادت جميع الخواص الفيزيائية والكيميائية قيد الدراسة. كما زاد النيتروجين الكلي وإنتاجية محصول الفاصوليا مع زيادة معاملات النانو سيليكا (Si-NP) حتى 200 جزء في المليون ثم تتاقص مع زيادة Si-NP لحد 400 جزء في المليون. 